\title{
American Perceptions of the European Union and Its Role in World Affairs
}

\author{
Yannis A. Stivachtis ${ }^{1}$ \\ ${ }^{1}$ Department of Political Science, Virginia Tech, VA, USA \\ Correspondence: Yannis A. Stivachtis, Department of Political Science, Virginia Tech, 119 Major Williams Hall, \\ Blacksburg, VA 24061, USA. Tel: 1-540-231-5816. E-mail: ystivach@vt.edu
}

Received: November 24, 2011 Accepted: April 26, 2012 Online Published: July 1, 2012

doi:10.5539/res.v4n3p64

URL: http://dx.doi.org/10.5539/res.v4n3p64

\begin{abstract}
There is a general consensus that the European Union (EU) has become a very important and influential international actor. In this process, the EU Member States have developed their own understanding and justification of the EU's international role. However, there is a growing interest in exploring whether there are any gaps between how the EU understands and presents itself to the world and how 'Others' perceive its role. This article investigates the American perceptions of the EU and its international role. Drawing on the theoretical and historical framework of the English School, the article explores the American perceptions against the historical development of the relations of the United States with various European states and the EU as a whole. It argues that American perceptions of the EU and of its international role have little or nothing to do with the American experience with European colonialism and imperialism. The existence of strong cultural, political, economic, and social ties between the U.S. and the European countries explains why the EU is trusted so much by the American public. Therefore, the divergence between the U.S. and the EU occurs within the bonds of a family of states that distinguishes itself from the rest of the international society.
\end{abstract}

Keywords: European Union, United States, US-European relations, international society, perceptions, foreign policy

\section{Introduction}

Despite the financial problems that it currently faces, it seems that there is a general consensus that the European Union (EU) has become a very important and influential international actor. This influence can easily be seen in the trade sector where the EU constitutes a major world commercial power. But the development of European Security and Foreign Policy (ESFP) and the involvement of the EU in various military operations abroad have also demonstrated that the EU plays an increasingly important and influential role in world politics. In this process, the EU Member States have developed their own understanding and justification of the EU's international role. However, there is a growing interest among scholars and analysts to explore whether there are any gaps between how the EU understands and presents itself to the world and how 'Others' perceive its role. Therefore, the purpose of this article is to investigate the American perceptions of the EU and of its international role.

Initially, the article intended to focus on North American perceptions, in general, rather than only on the perceptions held by the U.S. public. However, the lack of extensive and easily comparable data has prevented the inclusion of Canada and Mexico into this study. Nevertheless, the case of the U.S. is extremely important and indicative for two reasons: first, the U.S. was the first country that obtained its independence from the European colonial powers; and second, it quickly managed to dominate the Western Hemisphere by challenging the European powers and eventually became the central pillar of the global society of states.

According to Diez and Whitman (2002), in setting a research agenda for the analysis of European integration in terms of the English School (ES), the concepts of international society, world society, and empire are of special importance. Since the EU behaves as an international society with a particular regional flavor embedded in a 
larger global international society, this perspective allows for an investigation of the EU's international role. It has been argued that the actions of the EU matter to states in all regions of the world (Lucarelli \& Fioramonti, 2010; McGuire \& Smith, 2010). To the extent that the EU has become one of the most important global political actors, it is reasonable to expect that the EU's role is to a significant degree impacted by its perceptions abroad. Following Diez's and Whitman's suggestion that international society is "discursively created and upheld" (Diez \& Whitman 2002, p. 44), focusing on the public perceptions of the EU can shed light on the difference between the EU's own claims about its actions and what the rest of the world has to say. For other states, the ways in which they keep the EU at a distance by discursively constructing it will be reflected in popular discourse and public opinion. Furthermore, the EU's legitimacy today is partially a product of the historical relationship between the European international society and the rest of the world. This means that the EU today carries a significant amount of historical, cultural, and political baggage as it relates with other actors.

One way to assess the effectiveness of the diffusion and application of international norms is to consider elite and public opinion. In this case, the public perception of the EU may serve as an important indicator of the existence, maintenance, and success of European interpretations of international norms as well as the pursuing of EU norms at a global level.

Most publics external to the EU do not have a great deal of knowledge about the EU, problematizing the significance of public opinion on the role of the organization. According to Lucarelli and Fioramonti, "the EU's political and social image is still fragmented, while the European project remains vastly unknown to the citizens of non-European countries" (Lucarelli and Fioramonti 2010, p. 218). This general lack of knowledge on the EU may explain the impact of EU norms in two different ways. First, the lack of professed knowledge or understanding of the EU and its international role may imply that the international norms that the EU advocates have not been well diffused. If no one knows about them, then they have only minimal impact when clearly articulated. Since public opinion significantly affects the foreign policies of liberal democracies, such as the U.S., if publics are unconvinced or skeptical about the EU, the EU's foreign policy aspirations will be frustrated. Conversely, the general lack of knowledge of the EU could mean that the diffusion of the norms that the EU advocates has been such a success that the public can not distinguish any meaningful difference between it and what is reflected in their own state's foreign policy. A public that has little knowledge to distinguish among actors is likely to support an organization with little perceptible difference based on face information. Thus, the EU can be more ambitious in its foreign policy goals so far as other states support its agenda.

In order to provide a comprehensive examination and explanation of the American perceptions about the EU and its international role, this article will be divided into two parts. The first part will provide the article's theoretical framework by focusing on the work of the English School of International Relations, while the second part will focus on the U.S. and will explore the perceptions of the American public about the EU and the US-EU relations.

The article will explore the American perceptions against the historical development of the relations between the U.S. and various European states as well as with the EU as a whole. In so doing, it will address questions such as: have these perceptions of the EU and its role in world affairs anything to do with the American historical experiences with European colonialism or are these perceptions are associated with the national interests and global position of the U.S. and the image it wishes to portray internationally?

\section{The Expansion of the European International Society in North America}

One of the most prominent areas of ES inquiry is the historical expansion of the European society of states and its gradual transformation to the contemporary global international society (Bull \& Watson 1984; Gong 1984; Watson 1992; Stivachtis 1998). When the expansion began, the world was not organized into any single international society. Rather it comprised several regional international societies each with its own distinctive rules and institutions reflecting dominant regional culture. All these regional international societies were built upon elaborate civilizations, including distinctive religions, different systems of governance, different types of law, and different conceptions of the world and ways of conducting relations (Bozeman 1960). This is turn implies that relations between political communities that were members of different regional international societies could not be conducted on the same moral and legal basis as relations within the same society, because the rules of each individual regional international society were culturally particular and exclusive. There was no single agreed body of rules and institutions operating across the boundaries of any two or more regional international societies to speak for a broad international society. Thus the emergence of a truly global international society would not be possible unless one of the regional international societies could expand itself to the degree that it could combine the divergent regional international societies into a single universal society organized around a common body of rules and institutions. It was European international society which 
expanded gradually and brought other regional international societies into contact with one another (Bull 1984). It follows that European international society was superimposed on regional international societies, thereby transforming these into a global international society.

When the Europeans embarked on expansion they did so with a set of assumptions about relations with non-European and non-Christian peoples inherited from medieval Latin Christendom and the ancient world. Natural Law provided the normative basis for regulating relations among nations and with private traders throughout the world, not only within Christendom. The Europeans later developed the conception of the 'Law of Nations' that was common to all political communities and could be used to regulate relations among political entities that existed beyond and within the bounds of Christendom. The ideas of Natural Law and the Law of Nations were, however, often contested by conceptions postulating a fundamental division of humanity between Christians and infidels, and between Europeans and non-Europeans (Stivachtis 1998, p. 74).

The voyages of Christopher Columbus marked the beginning of an era when European culture pushed outwards from its homeland and gradually replaced or transformed the culture beyond its borders. Using their technological and scientific advantage, the Europeans set out to Europeanize and modernize the non-European world (Howard 1984). Whether or not the non-European world welcomed this European enterprise, it found it difficult to resist.

The discovery of Americas gave rise to doctrinal disputes concerning the status of overseas political communities. According to these doctrines, the distinction between Europeans and non-Europeans was supplemented by a further distinction between 'civilized' and 'non-civilized' people. The Europeans considered that their civilization had the absolute right to expand and impose itself, and that it was their mission to carry out the banner of their civilization into barbarous lands (Gong 1984; Bowden 2009). The existence of Natural Law arguments did not prevent the exploitation of American communities and the evolution of European self-definition along civilizational lines. The result of this exploitation was the destruction of indigenous civilizations and their replacement by colonial states formed according to the European archetype (Stivachtis 1998 , p. 80). It is worth mentioning that no single American state was a restoration of a pre-discovery community. Thus the process of European expansion marks a sharp discontinuity between the original American societies and the new European dependent states which came into being (Elliott, 1972, p. 27). From the beginning these states were viewed as an extension of Christian Europe, having a European form and run by Europeans.

Britain and France established colonial states in the Caribbean and North America. However, these colonies, unlike those of Spain and Portugal, experienced the direct rule of the European emigrants more than the central rule of the 'mother state'. To manage their affairs, the European settlers developed an autonomous system of administration similar to those of their homelands and they acquired consequently the necessary experience required for independent statehood and membership in international society. Nevertheless, all the European colonies were tied to their homelands in terms of culture as well as in economic and trade terms.

Most European states viewed colonies as an extension of their frontiers. The colonies thus increasingly influenced the policies of European great powers, such as Britain, France, and Spain. The idea that states might be in conflict in other parts of the world and still remain at peace in Europe became quickly outdated. Colonial events no longer took place in a different political world. The Anglo-French and Anglo-Spanish rivalries in North America demonstrated how things had changed in this respect.

The effective pressures towards independence from metropolitan control came from the European settlers. In all American colonies, prominent settlers were involved in local government to a greater or lesser extent: on the one hand, through elected assemblies in the British territories and, on the other hand, by appointments under the Crown (Watson 1984, p. 132). The European settlers had the necessary political consciousness and awareness as well as the experience of how a 'civilized' government should operate in order to make self-government plausible and acceptable to a large section of European governments and public opinion. Most important, they understood the techniques of European warfare well enough to push out the imperial authority where it did not hand over power voluntarily.

The legitimacy of multiple independencies thus inspired an increasing number of European settlers in the Americas, who wanted to disassociate themselves from dependence on one European state and involvement in the European balance of power, and look after their own interests as independent members of international society. When certain colonists began to perceive their interests as distinct from those of the 'mother country', the colonial connection seemed to them an entanglement, diverting them from their natural course of development. Their aim was to disentangle themselves from the quarrels and exigencies of Europe altogether, to 
trade with whatever markets suited them and to concentrate on the problems which faced them. They wanted to disengage strategically not merely from their imperial member of the system (mother country) but from the system itself (Watson 1984, p. 136). The Monroe Doctrine constitutes the best illustration of this fact.

Once a colony decided to proclaim itself a separate state by armed rebellion, it had just to counterbalance the military power of the 'mother country' by accepting the readily offered aid of that country's European enemies of the moment. At that stage the newly independent state became a new member of the European society of states (Stivachtis 1998, p. 79). During this process, the European states assumed that these new recruits to their society would continue to behave in the same way as they themselves felt constrained to do, namely that for some time at any rate the weight of the new state would be brought to bear, in self-defence, against the former imperial power and thus in favor of its enemies (Watson 1984, p. 136).

The independent European settler states regarded themselves as holders of European culture and civilization. They were also regarded in Europe as members of one family. What made them members of the European family was the process of their articulation, namely that they were all states after a European model, inhabited or dominated by people carrying the European culture.

The United States was the first American political community to be admitted to international society following its independence of 1776 by armed secession from Britain with the assistance of France, Britain's main opponent. Like all other American political communities, the U.S. was dominated and largely settled by Europeans and based on European principles and traditions.

In reference to the contemporary American perceptions of the EU and its international role, the ES study of the expansion of European society of states and the entry of the U.S. into international society leads to two important hypotheses. First, because of their historical ties and cultural similarities, the EU would be seen favorably by the American public. Consequently, the EU's role in world affairs would be perceived as positive; especially in comparison with other contemporary great powers like China and Russia. Second, any differences between the U.S., on the one side, and the EU, on the other, would be perceived as differences within the same 'community'. This would correspond to Barry Buzan's claim that within the heterogeneous global international society, there are more homogeneous regional international societies (Buzan 1993). It would also highlight the argument according to which North America and Europe form a homogeneous transregional international society that can easily be distinguished from its external environment. (Stivachtis 2008).

\section{American Perceptions of the $\mathbf{E U}$ and Its Role in World Affairs}

In order to address the questions mentioned in the introductory part of this paper and examine the validity of the hypotheses stated above, this part will be divided into two sections. The first section will provide an overview of the historical development of U.S.-European relations, while the second section will present and analyze the American public's perceptions about the EU and its international role.

\subsection{US-European Relations in Historical Perspective}

The study of the history of US-European relations demonstrates that despite their similarities in economic and political outlook, their need to work together to meet common threats, and their shared preferences on many issues, the U.S. and the EU Member States have pursued different policies on a number of issues. Steven Mcguire and Michael Smith (2008) have provided an excellent analysis of the US-EU relations identifying clearly the points and issues of convergence and divergence between the two sides. According to McGuire and Smith (2008, p. 265), disagreements between the two sides reflect deeply held differences informed by history and society, often sharpened by the evolution of the broader world arena. These differences, however, are usually managed through a number of processes, such as transatlantic governance and crisis management (Stephenson 2010).

Competition between the U.S. and the EU is seen most in the economic realm, where despite a shared preference for the market economy, alternative visions of the extent and operations of that market persist (Petersmann \& Pollack 2004). The EU remains much more attached to a social market competition with relatively higher taxation and a larger role for the state. But even in the economic realm, one can easily identify points of convergence.

Processes of competition and convergence are also discernible in the political realm, where the search for international order and stability entails not only economic and commercial relations but also those of diplomacy and of security policy (McGuire \& Smith 2008, p. 266). The competition between the EU and the U.S. for presence in major world regions is often informed by the idea that the two sides are in a competition for global advantage, based on their contrasting attitudes towards economic organization, political order, and the pursuit of 
values, such as security and development (Ress 2011). For example, the EU emphasizes its role as a 'civilian' power and the use of 'soft power', as opposed to the U.S., who is more willing to use its military/hard power. This does not always mean that the core preferences and priorities of the EU and the U.S. diverge. It rather means that the chosen instruments for pursuit of those preferences and priorities can be markedly different. However, as McGuire and Smith have shown, the competition also gives evidence of a common set of EU and U.S. interests centering on stability, market economics, and democratic politics (McGuire \& Smith 2008, chapters 8 and 9). The examination of the historical development of US-European relations will highlight and underline the points raised above (Herring 2008; Hunt 1994).

The military and financial alliance with France in 1778, which brought in Spain and the Netherlands to fight the British, turned the American Revolution into a major war in which the British naval and military supremacy was significantly challenged. As a result, the European settlers managed to overthrow the British rule and the U.S. became an independent and sovereign state. From the establishment of the United States after the American Revolution until the Spanish-American War, U.S. foreign policy reflected a regional rather than a global focus (Ambrose 1988; Perkins 1993; Hensel 2002; Paap et al. 2004). The primary foreign policy objective during this period was the prevention of European interference both in the domestic affairs of the U.S. and the country's external relations with its immediate neighbors. Therefore, when the French Revolution led to war in 1793 between Britain and France, George Washington decided on a policy of neutrality. In 1795 Washington supported the Jay Treaty, designed by Treasury Secretary Alexander Hamilton, to avoid war with Britain and encourage commerce. Despite domestic opposition by the Jeffersonians, Washington's support proved decisive, and the U.S. and Britain remained on friendly terms for a decade.

In his "Farewell Message", President George Washington in 1796 counseled against foreign entanglements:

"Europe has a set of primary interests, which to us have none, or a very remote relation. Hence she must be engaged in frequent controversies, the causes of which are essentially foreign to our concerns. Hence therefore it must be unwise in us to implicate ourselves, by artificial ties, in the ordinary vicissitudes of her politics, or the ordinary combinations andcollisions of her friendships, or enmities. Our detached and distant situation invites and enables us to pursue a different course." (cited in Ambrose 1988, p. 37).

Washington's argument reflected the traditional wish of the European settlers to disengage strategically both from individual European powers and the European system itself. No surprise therefore that Washington's point of view eventually became the foundation of U.S. policy under the Monroe Doctrine.

By 1797 the French navy was openly seizing American ships, leading to an undeclared conflict known as the Quasi-War of 1798-99. When Thomas Jefferson came to power, he envisioned the U.S. as the force behind a great "Empire of Liberty" that would promote republicanism and counter the imperialism of the British Empire. With the Embargo Act of 1807, Jefferson forbade trade with both France and Britain. The Jeffersonians deeply distrusted the British. In the west, Indians supported by Britain (but not under their control) used ambushes and raids to eliminate settlers, thus delayed the expansion of frontier settlements into the Midwest.

In 1812 diplomacy had broken down and the U.S. declared war on Britain, which ended with the Treaty of Ghent in 1815. Militarily it was a stalemate as both sides failed in their various military attempts, but the British Royal Navy blockaded the coastline and shut down American trade. However, the American armies defeated the Indian alliance that the British had supported, ending the British war goal of establishing a pro-British Indian boundary nation in the Midwest. On the other hand, Anglo-American tensions continued to exist for sometime along the U.S-Canada border where many loyalists had immigrated following the independence of the United States. After 1815 tensions de-escalated along the U.S.-Canada border, with peaceful trade and generally good relations. Boundary disputes were settled amicably. At the same time, the U.S. saw a surge in nationalism and national pride.

In response to the new independence of Spanish colonies in Latin America in the early nineteenth century, the U.S. established the Monroe Doctrine in 1823. This policy declared opposition to European interference in the Americas and left a lasting imprint on the psyche of later American leaders (LaFeben 1993; Guinsburg 1994).

The issue of slavery in the western territories then exploded and the U.S. turned inward. Under Abraham Lincoln, the North mobilized its superior industrial, financial, and population resources and its forces blockaded the South and prevented Europe from intervening. France, which had meanwhile taken control of Mexico, was forced out by American threats. American relations with Britain and Canada were again tense until the arbitration of the Alabama Claims in 1872 provided a satisfactory reconciliation. 
In early 1893, fierce fighting between U.S. and Spanish warships off the coast of Cuba led to the sinking and grounding of several Spanish battleships. In the late nineteenth century, the U.S. began investment in new naval technology including steam-powered battleships with powerful armaments and steel decking. When its battleship the USS Maine was blown up for undetermined reasons in the harbor of Havana, Spain was blamed for the loss of the U.S. battleship. The four-month long Spanish-American War from April through July 1898 was a brief, intense conflict that effectively ended Spain's worldwide empire, and brought the U.S. new territories in Cuba, Puerto Rico, the Philippines and Guam. It also marked America's transition from a regional to a global power (Hensel 2002, p. 5; Fry 1994). The U.S. Navy emerged as a major naval power thanks to modernization programs begun in the 1880s and adopted the sea power theories of Alfred Thayer Mahan. The Army remained small but was reorganized during the Roosevelt Administration along modern lines. The Philippine-American War was a short operation to suppress insurgents and ensure U.S. control of the islands. By 1907, however, interest in the Philippines as an entry to Asia faded in favor of the Panama Canal, and American foreign policy centered on the Caribbean.

The rising of the U.S. to a global power status continued in the early twentieth century. The 1904 Roosevelt Corollary to the Monroe Doctrine, which proclaimed a right for the U.S. to intervene to stabilize weak states in the Americas, further weakened European influence in Latin America and further established U.S. regional hegemony.

Gradually, the growing power of the U.S. started having an impact on the minds of certain American leaders, such as President Wilson, who saw an opportunity for the U.S. to increase its international role beyond the Americas (Iriye 1993; Coogan 1994; Holladay 2010). With the outbreak of war in 1914, the U.S. declared neutrality and worked to broker a peace. It insisted on its neutral rights, which included allowing private corporations and banks to sell or loan money to either side. With the British blockade, there were almost no sales or loans to Germany, only to the Allies. President Wilson vehemently denounced German violations of American neutrality that involved loss of life, most famously in the torpedo attack on the Lusitania in 1915 that killed 128 American civilians. However, there has been some evidence that Lusitania may have been carrying war munitions. Germany repeatedly promised to stop attacks by its submarines, but reversed course in early 1917 when it saw the opportunity to strangle Britain by unrestricted submarine warfare. Following the sinking of American merchant ships, Wilson asked and obtained a Declaration of War in April 1917. During the war, the U.S. was not officially tied to the Allies by treaty, but military cooperation meant that the American contribution became significant in mid-1918. After the failure of the German spring offensive, as fresh American troops arrived in France at 10,000 a day, the Germans were in a hopeless position and surrendered. Coupled with Wilson's Fourteen Points in January 1918, the U.S. now had the initiative on the military, diplomatic, and public relations fronts.

At the Peace Conference at Versailles, Wilson tried with mixed success to enact his Fourteen Points. He succeeded in obtaining his main goal, a League of Nations that would hopefully resolve all future conflicts before they caused another major war. But the U.S never joined the League of Nations. Nevertheless, Wilson's idealistic vision of spreading democracy and peace under American auspices had a profound influence on much of American foreign policy ever since.

During the early phases of the Second World War, U.S. pursued a policy of neutrality but which substantially favored Britain and its allies. The U.S. made large-scale grants of military and economic aid to the Allies through the Lend-Lease program. Industries greatly expanded to produce war materials. The U.S. officially entered World War II against Germany, Japan and Italy in December 1941, following the Japanese surprise attack on Pearl Harbor.

After the war and devastation of its European and Asian rivals, the U.S. found itself in a uniquely powerful position due to the lack of damage to its domestic industries. At the same time, the U.S. found itself in direct competition with a growing major global power: the Soviet Union. As a result, the U.S. emerged from the Second World War as a global power with global interests and therefore the isolationist pattern characterizing the U.S. foreign policy during the inter-war period was ended for good.

From the late 1940s until 1991, world affairs were dominated by the Cold War, in which the U.S. and its allies faced the Soviet Union and its allies. There was no large-scale fighting but instead numerous regional wars as well as the ever-present threat of a catastrophic nuclear war. The U.S. actively sought allies, which it subsidized with military and economic foreign aid, as well as diplomatic support. It is against this background that the post-World War II US-European relations should be analyzed. 
The relationship between the EU and the US is one of the most important bilateral relationships in world politics. The two actors constitute major economic and military powers, they dominate global trade, and they play the leading roles in international political relations.

The EU has played a vital role in the post-1945 U.S. foreign policy and the two sides have held diplomatic relations since 1953. During the Cold War the project and process of European integration was vital to the interests of the U.S. for two reasons: first, the economic development of Western Europe could prevent the extension of Soviet influence on the European continent; and second, the process of integration could prevent the re-emergence of historical hostilities in Western Europe - especially between France and Germany - which could destabilize the region and provide the Soviet Union with opportunities to extent its influence westwards. After the end of the Cold War, the U.S. saw the EU as a means to integrate the states of Eastern Europe but also other states of vital importance, such as Turkey.

Because of their historical ties, their adherence to common international norms, and their common political and economic belief systems, the U.S. saw Western Europe/EU as a political partner and ally in the world arena (Lundestand 1998). However, neither during the Cold War nor in its aftermath was the U.S. willing to accept an equal partnership. Following the collapse of the Soviet Union, the U.S. wanted the EU to play a more active role in world affairs - mainly in support of U.S. policies and military operations - as well as increase its burden sharing in the military sector but never to the point that it could challenge the primacy of the United States.

Despite their commonalities, the U.S. and the EU have regularly disagreed with each other on a wide range of specific issues, as well as having often quite different political, economic, and social agendas. Understanding the relationship means reviewing developments that predate the creation of the European Economic Community (EEC).

In the aftermath of the European campaign and in an effort to prevent the spread of communism in Europe the U.S. enacted the Marshall Plan which supplied its European allies with thirteen billion USD in reconstruction aid. In addition, the Truman Doctrine and its associated military and economic aid assured that Greece and Turkey would remain under American influence. Moreover, the establishment of the North Atlantic Treaty Organization (NATO) provided Western Europe with a security guarantee in the face of Soviet threats.

Despite their common political, economic, and security interests, the U.S. and its European allies found themselves in major political disagreements and pursued different policies and strategies to serve their individual interests (Brown 1994; Cohen 1993). For example, during the Korean War Americans and Europeans differed on strategy, while the 1954 French defeat at Dien Bien Phu precipitated a tumultuous French withdrawal from colonial Empire and led to resentment at U.S. failure to help. The $1956 \mathrm{Suez}$ crisis, in which perceived U.S. betrayal of European allies caused considerable resentment, led to British withdrawal from colonial Empire. The 1962 Cuban missile crisis alarmed western Europeans not only because it took the world to the brink of nuclear war, but also because they were not fully appraised by the Kennedy administration. In 1966, France withdrew from the military structure of NATO emphasizing French distrust of U.S. foreign policy and international influence. The Vietnam War, opposed by political and public opinion in Western Europe, generated resentment in the U.S. because of the lack of European support. Willy Brandt's "Ostpolitik" alarmed the U.S. because of West German outreach to East Germany. In 1973 the Yom Kippur War created serious rift between Americans and Europeans. The 1990-91 Gulf war found the western Europeans deeply divided in the face of American military and political leadership, while the 2003 invasion of Iraq brought US-EU divisions out into the open.

In the 1980s under a program of extensive military spending led by President Reagan, as well as by diplomatic overtures between Reagan and Soviet leader Mikhail Gorbachev, a thaw resulted, which eventually led to the disintegration of the Soviet Union. With the breakup of the Soviet Union, the world of pro-U.S. and pro-Soviet alliances broke down. Different challenges presented themselves, such as climate change as well as the threat of nuclear terrorism. The big change during these years was a transition from a bipolar to a multipolar world. While the U.S. remains a strong power economically and militarily, rising powers such as China, India, and Russia as well as a united Europe have challenged its dominance (Hamilton 1989; Martel 1994).

The historical cases mentioned above demonstrate clearly that despite their similarities in economic and political outlook, their need to work together to meet common threats, and their shared preferences on many issues, the U.S. and the EU Member States have pursued different policies on a number of issues. As McGuire and Smith have argued, disagreements between the two sides reflect deeply held differences informed by history and society, often sharpened by the evolution of the broader world arena (McGuire and Smith 2008, p. 265).

Having examined the historical development of the US-European relations, it is interesting to see the effects, if any, of those relations on the American public opinion. Lef Johan Eliasson (2010) has provided a very 
interesting account of America's perception of Europe. However, Eliasson's work places emphasis on the commonalities and divergences between the two sides of the Atlantic in terms of values, norms, belief systems, and outlook of life. Therefore, it does not focus on the issues and questions that the present article seeks to address.

\subsection{American Perceptions of the EU and Its International Role}

In order to obtain a clear understanding of the American public's perceptions about the EU and its international role, public opinion will be recorded into five different albeit interrelated areas: knowledge about the EU, general perceptions about the EU, perceptions about the US-EU economic relations, perceptions about the US-EU political relations, and perceptions about the EU's role in world affairs.

\subsubsection{Knowledge about the European Union}

Generally speaking, the existing surveys and polls indicate that the American public's knowledge about the EU is relatively low. For example, according to a Gallup poll (16 June 2004), U.S. public knowledge of the EU found a remarkably high number of respondents (77\%) admitting they know very little or nothing about the organization. Only 3\% claimed to know a great deal about it. Relatively few Americans (20\%) correctly assessed the population of the EU Member States relative to that of the U.S., saying that EU is "larger".

The percentage of respondents saying that they know a great deal or fair amount about the EU rises from $11 \%$ among those with no more than a high school diploma to $48 \%$ among those with postgraduate education. However, the primary threshold for self-stated knowledge is having a college degree. Still, even among these highly educated Americans, less than half claimed to know a great deal or fair amount about the European Union. Overall, only 2 in 10 Americans correctly said that the EU is larger than the U.S., whereas 6 in 10 have an erroneous impression, saying that the EU is smaller than the U.S. (29\%), or that the two are about the same size (29\%). Another $22 \%$ had no opinion. Even those who professed to be fairly knowledgeable about the EU are more likely than not to get it wrong when asked to estimate the population of the EU relative to the U.S. population. Among those saying they know a great deal or fair amount about the EU, only $34 \%$ correctly stated that the EU's population is larger than that of the U.S., while $63 \%$ were even less likely to answer correctly, but, rather than provide a wrong answer, many admitted they didn't know.

A Pew Research poll taken in 2005 also indicated that many Americans are unfamiliar with the EU, as a majority said they had either never heard of it (14\%) or did not know enough about it to offer an opinion (26\%). Pew surveys have generally found that Americans pay relatively little attention to European affairs (Pew Research 2005a and 2005b).

The lack of familiarity with the EU can be to a large extent explained with reference to the dominant global position of the United States. Since the U.S. has been a superpower for quite sometime and has played a pivotal and dominant role in world affairs, the American public has become self-centric. As a result, international actors, like the EU, have not attracted the attention and curiosity of the American public. Instead, their role is seen as minimal and marginal. This implies that EU-sponsored norms and policies are almost irrelevant in the eyes of the large portion of the American public. However, among those who know fairly enough about the EU, it appears that EU norms are generally accepted and supported mainly because these norms and are also shared by the United States. To a large degree, this can be explained with reference to the historical ties and common values and traditions between the U.S. and the European Union.

\subsubsection{General Perceptions about the European Union}

The study of the relevant surveys shows that the American public's perceptions of the EU have been conditioned by two factors: first, the general lack of knowledge and unfamiliarity with what the EU is and does; and second, the tensions in the US-EU relations following the U.S. invasion of Iraq (Kotzias \& Liakouras 2005; Stivachtis 2004 \& 2006).

In February 2004, American views of the EU were more favorable than unfavorable though many in the U.S. have not formed an impression of the EU (Pew Research, March 16, 2004). Overall, 39\% had a favorable impression, while $26 \%$ an unfavorable view; $35 \%$ had no opinion. Views of the EU were largely unchanged since another poll that was taken in early September 2001, shortly after the 9/11 terrorist attacks.

According to a Pew Research poll conducted in 2005, the American public was not very enthusiastic about a strong EU; still $47 \%$ believed this would be a good thing, while $28 \%$ said it would not matter and only $12 \%$ said it would be bad for the United States. One-third of the public had a favorable opinion of the EU, while just over a quarter $(27 \%)$ had an unfavorable view. Opinions about the EU had grown slightly less positive since February 2004, when $39 \%$ had a favorable view and $26 \%$ an unfavorable one (Pew Research 2005a). 
However, as disagreement over the war in Iraq faded away, the American public's perceptions of the EU became more favorable. For example, in the Pew Global Attitudes Project Poll, conducted in May 2009, 56\% of the respondents said that they have a somewhat favorable or very favorable view of the EU and only $23 \%$ said that they hold a somewhat unfavorable or very unfavorable view. The same poll in March 2011 indicated that 55\% of the respondents held a somewhat favorable or very favorable view of the EU and only $22 \%$ said that they hold a somewhat unfavorable or very unfavorable view. Similar results were recorded in two other Pew Research surveys conducted in July 2009 and June 2010. The results of these surveys clearly indicate that despite certain disagreements, the Americans still see the EU in a positive way and they are confident about its positive impact in world affairs. Again, this can to a large degree be explained with reference to the historical ties and common values, norms, and traditions between the U.S. and the European Union.

\subsubsection{US-EU Economic Relations}

There is a general impression that competition between the U.S. and the EU is stronger in the economic realm. Nevertheless, survey results demonstrate that the American public is very favorable to the increase of economic interaction between the two sides. A July 2004 CCFR poll asked whether the U.S. practices fair trade with various other countries. In each case, a strong majority of two-thirds or better said that the U.S. practices fair trade. European Union countries scored 76\%. When CCFR asked whether the EU's trade policies were fair toward the U.S., 60\% said they were in both 2002 and 2004, up from 54\% in 1998 (cited in World Public Opinion 2005a). In 1998, Americans expressed widespread feeling that Europe is less open to American products than the U.S. is to European imports. PIPA found that $74 \%$ agreed with the statement "In general, European countries do not let in American goods as much as America lets in European goods" (20\% disagreed) (cited in World Public Opinion 2005a). In PIPA's April 1998 poll, 64\% also agreed that the U.S. should lower barriers to European products "if the countries of the European Union say they will lower barriers to products from the US" (cited in World Public Opinion 2005b).

But even in the economic realm, the American public is generally in favor of the stengthening of the US-EU commercial relations. For example, in a Pew Research poll conducted in $2010,58 \%$ of the respondents said that increased trade with the EU would be a good thing for the U.S. as opposed to $28 \%$ who indicated that this would be a bad thing. It is worth noting that the poll in question recorded the American public's preference for increased trade with Western (EU and Canada) or Western-oriented states (Japan). In contrast, the American public was very skeptical about trade with China with the majority indicating that this would not be desirable. Specifically, $45 \%$ of the respondents said that increased trade with China would be a "good" thing for the U.S. and $46 \%$ said it would be a "bad" thing (Pew Research 2010).

\subsubsection{US-EU Political Relations}

As in the case of the American public's general perceptions of the EU, perceptions of the political relations between the two sides have been conditioned by the tensions in the US-EU relations following the U.S. invasion of Iraq. In February 2004, despite disagreements with many traditional U.S. allies over the war in Iraq, a majority of Americans (55\%) believed that the partnership between the U.S. and Western Europe should remain as close as it has been (Pew Research 2004). Only 36\% thought the U.S. should take a more independent approach. Opinion was essentially unchanged from another Pew Research survey taken in May 2003. Just a third of the Americans said it would be a good thing for the EU to become as powerful as the United States.

According to a Pew Research poll conducted in 2005, both opinion leaders and the public strongly believed that the U.S. and Western Europe should maintain a close relationship. $84 \%$ of the public and over $78 \%$ in each group of opinion leaders said it is important for the US-Western Europe partnership to be as close as it has been in the past. Moreover, there was a solid consensus among opinion leaders that a stronger EU is a good thing for the United States. In each of the eight opinion leader groups identified in the survey, at least $60 \%$ said a stronger EU would be good for the U.S., while no more than $11 \%$ believe this would be a bad thing (Pew Research 2005a). These results clearly indicate a strong confidence in the EU as a political partner in world affairs, which merely reflects the strong historical and cultural ties existing between the U.S. and Europe.

\subsubsection{The EU in World Affairs}

The Gallup survey of 16 June 2004 aimed at measuring the perceived likelihood among U.S. nationals that the EU would ever become a superpower such as the United States. The survey showed that Americans who believe they are highly or fairly knowledgeable about the EU are much more likely than those with lower levels of self-stated knowledge to believe the EU is a contender for world superpower status. Nearly two-thirds of those in the high-awareness group (65\%) believe it is very or somewhat likely that the EU will one day become a superpower like the United States. This drops to $50 \%$ among those who say they know very little about the EU, 
and to $27 \%$ among those who indicate they know nothing about the organization. Americans are generally dubious; just $44 \%$ says is very or somewhat likely that the EU will ever become a superpower such as the United States. An equal number, $44 \%$, say it is not very or not at all likely, while an additional $12 \%$ are unsure.

The same poll also tested public impressions about whether the EU plays a positive or negative role with respect to economic growth, world peace, the war on terrorism, protection of the environment, and the fight against world poverty. Fewer than half of the Americans assume that the EU plays a positive role on each of these dimensions. A much smaller number say it plays a negative role, while one-third to one-half are neutral or have no opinion about its role in these matters.

A parallel question asked Americans to assess the U.S. role in the world on these dimensions, and helps to put the public's view in some context. In every instance, larger percentages of Americans say the U.S. plays a positive role than say this for the European Union. There are however, some interesting differences in the way Americans evaluate the U.S. and the EU on the various dimensions; differences that may tell much about the way Americans view their own country as they do about the way Americans view the European Union. The Gallup poll summarizes these ratings by showing the "net positive" score for each objective both the U.S. and the European Union. On this basis, there is one area in which the EU is rated more positively than the U.S.: protection of the environment (26\% net positive score for the EU vs. $15 \%$ net positive score for the United States). The EU also fares relatively well on dealing with world peace. The U.S. is rated much more positively than the EU on dealing with the world economy, fighting poverty, and most notably, dealing with terrorism.

As previously, Americans with high levels of self-state knowledge of the EU are somewhat more likely than those who know very little, and much more likely than those who say they know nothing about the EU, to believe the EU plays a positive role in most areas the survey asked about. In fact, the high-awareness group gives the EU a higher net positive rating with respect to the world economy than Americans generally give to the U.S. (61\% to $49 \%$ ) (Gallup 2004).

According to World Public Opinion (2006a), 53\% of the Americans think the EU has a constructive impact on the world, while $20 \%$ think otherwise. This indicates that Americans became more positive about the EU since the Gallup survey of 16 June 2004, with favorable views up 11 points from $42 \%$. This change can be attributed mainly to the fading of US-EU disagreement over the war in Iraq.

The prospect of the EU becoming a parallel superpower elicits a pluralistic view. The German Marshall Fund in May 2005 asked whether the respondents agreed more that "the U.S. should remain the only superpower" or "the EU should become a superpower like the United States". Only 36\% said that the U.S. should remain the only superpower. Rather a majority of $47 \%$ said that the EU should become a superpower (cited in World Public Opinion 2006a). When asked abstractly whether the U.S. should try to maintain its role as the only superpower a plurality or slight majority says that it should. But when asked specifically about the prospect of the EU becoming a comparable power Americans are remarkably sanguine. When asked about sharing military dominance on a global scale, half of the Americans prefer to maintain the United States' status as the sole superpower, but this is not strongly felt as the position is rather easily abandoned. In an October 2005 Pew poll, a plurality $(50 \%)$ said that in the future U.S. policies should try to "keep it so America is the only superpower". However, only $23 \%$ said that this should be the policy even if it "risks alienating principal allies," while $22 \%$ would not want to pursue this policy in that situation. Thirty-five percent initially take the position that it would be acceptable if the EU became as militarily powerful as the United States (cited in World Public Opinion 2006b). When the Chicago Council asked in 2006 whether the U.S. should "make active efforts to ensure that no other country becomes a superpower", $49 \%$ said that it should, down from a slight majority of $52 \%$ in 2004 (cited in World Public Opinion 2006b).

In March 2011, the German Marshall Fund conducted another poll asking "how desirable is it that the European Union exert strong leadership in world affairs?" $83 \%$ of the general public said that it was either somewhat desirable or very desirable and only $16 \%$ said that it was somewhat undesirable and very undesirable. $91 \%$ of the American leaders said that it was either somewhat desirable or very desirable and only $9 \%$ said that it was somewhat undesirable and very undesirable. As previously, these results strongly indicate a significant confidence in the EU as a leader in world affairs, which merely reflects the existence of strong historical and cultural ties between the U.S. and Europe.

\section{Conclusion}

The purpose of this article was to explore the American perceptions of the EU and its role in world affairs. In so doing, it sought to address two important questions: first, have these perceptions of the EU anything to do with 
the American historical experiences with European colonialism; and second, are these perceptions associated with the national interests and global position of the U.S. and the image it wishes to portray internationally?

The survey and poll data used in this article have indicated that American perceptions of the EU and of its international role have little or nothing to do with the American experience with European colonialism and imperialism. The fact that the U.S. was established by European settlers and structured as well as governed according to the European archetype of state indicates a historical cultural and political continuity. Once the U.S. became an independent and sovereign state, those settlers view their country as being part of the same family of states although they wanted to play a more independent role within the bonds of that family. The existence of strong cultural, political, economic, and social ties between the U.S. and the European countries explains why the EU is trusted so much according to the survey and poll results; especially when compared with other major powers such as China and Russia.

The divergence between the U.S. and the EU can be explained in two ways. First, despite their many similarities, American and European societies have historically developed in different ways; and second, the U.S. managed to achieve a predominant place in the international system and it doesn't wish its position to be challenged. But this U.S. stance is not different from the one that the European great powers held in the era of colonialism and imperialism as they didn't also wish the political communities in the Americas to challenge their own position in world affairs. But as it was mentioned previously, such divergence occurs within the bonds of a family of states that distinguishes itself from the rest of the international society.

A secondary goal of this article was to investigate the effect of American public opinion on the acceptance and support of EU sponsored international norms. The analysis of surveys and polls indicate that the lack of familiarity with the EU can be to a large extent explained with reference to the dominant global position of the United States. Since the U.S. occupies a quite dominant position in the international system, the American public has become self-centric. As a result, international actors, like the EU, have not attracted the attention and curiosity of the American public. Instead, their role is seen as minimal and marginal. This implies that EU-sponsored norms and policies are almost irrelevant in the eyes of the large portion of the American public. However, among those who know fairly enough about the EU, it appears that EU norms are generally accepted and supported mainly because these norms and are also shared by the United States. To a large degree, this can be explained with reference to the historical ties and common values and traditions between the U.S. and the European Union.

\section{Acknowledgements}

The author would like to thank Mike Hebegger for his invaluable contribution to the preparation of this paper.

\section{References}

Ambrose, S. E. (2010). Rise to Globalism: American Foreign Policy Since 1938 (9 $9^{\text {th }}$ edition). New York: Longman.

Bowden, B. (2009). The Empire of Civilization: The Evolution of an Imperial Idea. Chicago: Chicago University Press.

Bozeman, A. (1960). Politics and Culture in International History. Princeton, NJ: Princeton University Press.

Brown, S. (1994). The Faces of Power: Constancy and Change in United States Foreign Policy (2 ${ }^{\text {nd }}$ edition). New York: Columbia University Press.

Bull, H. (1984). The Emergence of a Universal International Society. In H. Bull, \& A. Watson (Eds.), The Expansion of International Society (pp. 117-26). Oxford: Clarendon Press.

Bull, H., \& Watson, A. (Eds.) (1984). The Expansion of International Society. Oxford: Clarendon Press.

Buzan, B. (1993). From International System to International Society: Structural Realism and Regime Theory Meet the English School. International Organization, 47, 327-352. http://dx.doi.org/10.1017/S0020818300027983

Cohen, W. I. (1993). America in the Age of Soviet Power, 1945-1991. The Cambridge History of American Foreign Relations (vol. 4). Cambridge: Cambridge University Press.

Coogan, J. W. (1994). Wilsonian Diplomacy in War and Peace. In G. Martel (Ed.), American Foreign Relations Reconsidered, 1890-1993 (pp. 71-89). London: Routledge. 
Diez, T., \& Whitman, R. (2002). Analysing European Integration: Reflecting on the English School - Scenarios of an Encounter. Journal of Common Market Studies, 40(1), 43-67. http://dx.doi.org/10.1111/1468-5965.00343

Eliasson, L. J. (2010). America's Perceptions of Europe. Basingstoke: Palgrave. http://dx.doi.org/10.1057/9780230109605

Elliott, J. H. (1972). The Old World and the New, 1592-1650. Cambridge: Cambridge University Press.

Fry, J. A. (1994). Imperialism, American Style, 1890-1916. In G. Martel (Ed.), American Foreign Relations Reconsidered, 1890-1993 (pp. 52-70). London: Routledge.

Gallup News Service. (2004). Americans Know Little about European Union, 16 June 2004, Retrieved September 12, 2011, from http://www.gallup.com/poll/12043/americans-know-Little-About-Europe

Gong, G. (1984). The "Standard of Civilization” in International Society. Oxford: Clarendon Press.

Guinsburg, T. N. (1994). The Triumph of Isolationism. In G. Martel (Ed.), American Foreign Relations Reconsidered, 1890-1993 (pp. 90-105). London: Routledge.

Hamilton, E. K. (Eds.) (1989). America's Global Interests. New York: Norton.

Hensel, H. M. (2002). American National Interests and Objectives. In H. M. Hensel (Eds.), The United States and Europe: Policy Imperatives in a Globalizing World (pp. 1-54). Aldershot: Ashgate.

Herring, G. C. (2008). From Colony to Superpower: U.S. Foreign Relations Since 1776. Oxford: Oxford University Press.

Holladay, L. J. (2010). From Isolation to Leadership: a Review of American Foreign Policy. New York: Forgotten Books.

Howard, M. (1984). The Military Factor in European Expansion. In H. Bull, \& A. Watson (Eds.), The Expansion of International Society (pp. 33-42). Oxford: Clarendon Press.

Hunt, M. H. (1994). Traditions of American Diplomacy: From Colony to Great Power. In G. Martel (Ed.), American Foreign Relations Reconsidered, 1890-1993 (pp. 1-20). London: Routledge.

Iriye, A. (1993). The Globalizing of America, 1913-1945. The Cambridge History of American Foreign Relations (vol. 3). Cambridge: Cambridge University Press.

Kotzias, N., \& Liacouras, P. (Eds.) (2005). EU-US Relations: Repairing the Transatlantic Rift. Basingstoke: Palgrave.

LaFeben, W. (1993). The American Search for Opportunity, 1865-1913. The Cambridge History of American Foreign Relations (vol. 2). Cambridge: Cambridge University Press.

Lucarelli, S., \& Fioramonti, L. (2010). The EU in the Eyes of Others - Why Bother?. In S. Lucarelli, \& L. Fioramonti (Eds.), External Perceptions of the European Union as a Global Actor. London: Routledge.

Lundestand, G. (1998). Empire by Integration: The United States and European Integration, 1945-1997. Oxford: Oxford University Press.

Martel, G. (ed.) (1994). American Foreign Relations Reconsidered, 1890-1993. London: Routledge.

McGuire, S., \& Smith, M. (2008). The European Union and the United States: Competition and Convergence in the Global Arena. Basingstoke: Palgrave.

Papp, D. S., Johnson, L. K., \& Endicott, J. (2004). American Foreign Policy: History, Politics, and Policy. New York: Longman.

Perkins, B. (1993). The Creation of a Republican Empire, 1776-1865. The Cambridge History of American Foreign Relations (vol. 1), Cambridge: Cambridge University Press.

Petersmann, E., \& Pollack, M. A. (2004). Transatlantic Economic Disputes: the EU, the US, and the WTO. New York: Oxford University Press.

Pew Research Center. (2004). A Year After Iraq War: Mistrust of America in Europe ever Higher, Muslim Anger Persists. 16 March 2004. Retrieved September 12, 2011, from http://people-press.org/2004/03/16/additional-findings-and-analyses 
Pew Research Center. (2005a). America's Place in the World: Opinion Leaders Turn Cautious, Public Looks Homeward, 17 November 2005. Retrieved September 12, 2011, from http://people-press.org/2005/11/17/iv-allies-trade

Pew Research Center. (2005b). America's Place in the World: Opinion Leaders Turn Cautious, Public Looks $\begin{array}{lllll}\text { Homeward. } & \text { Retrieved } & \text { September } & \text { 12, } & \text { from }\end{array}$ http://people-press.org/2005/11/17/opinion-leaders-turn-cautious

Pew Research Center. (2009). Pew Global Attitudes Project Poll. Retrieved October 25, 2011, from http://www.people-press.org/question-search/?qid=1744127\&pid=51\&ccid

Pew Research Center. (2010). Americans Are of Two Minds on Trade. Retrieved September 20, 2011, from http://pewresearch.org/pubs/1795/poll-free-trade-agreements

Pew Research Center. (2011). Pew Global Attitudes Project Poll. Retrieved October 25, 2011, from http://www.people-press.org/question-search/?qid=1788664\&pid=51\&ccid

Ress, W. (2011). The US-EU Security Relationship: The Tensions between a European and a Global Agenda. Basingstoke: Palgrave, Macmillan.

Stephenson, R. (2010). Managing EU-US Relations: Actors, Institutions, and the New Transatlantic Agenda. Manchester: Manchester University Press.

Stivachtis, Y. (1998). The Enlargement of International Society. New York: St. Martin's Press.

Stivachtis, Y. (2004). Common Foreign and Security Policy (CFSP) and European Security and Defense Policy (ESDP) after Iraq. In Yannis, A. S. (ed.), Current Issues in E.U.ropean Integration (pp. 117-42), Athens: ATINER.

Stivachtis, Y. (2006). EU-American Relations and the Future of Transatlantic Cooperation. In S. F. Krishna-Hensel (Eds.), Global Cooperation: Challenges and Opportunities in the Twenty-First Century (pp. 147-170). Aldershot: Ashgate.

Stivachtis, Y. (2008). The Overlapping of Regional International Societies: The Case of the Transatlantic Community and the European Union. In A. Kalaitzidis (ed.), Global Politics in the Dawn of the $21^{\text {st }}$ Century (pp. 383-409). Athens, ATINER.

The German Marshall Fund of the United States. (2009). Polling the Nations: European Union, 23 July 2009.

The German Marshall Fund of the United States. (2010). Polling the Nations: European Union, 17 June 2010.

The German Marshall Fund of the United States. (2011). Polling the Nations: European Union, 15 March 2011.

Watson, A. (1984). New States in the Americas. In H. Bull, \& A. Watson (Eds.), The Expansion of International Society (pp. 127-42). Oxford: Clarendon Press.

Watson, A. (1992). The Evolution of International Society. London: Routledge. http://dx.doi.org/10.4324/978 0203415726

World Public Opinion. (2005a). International Trade: Reservations About the Effects of Trade in Practice. Retrieved September 20, 2011 from http://www.americans-world.org/digest/global_issues/intertrade

World Public Opinion. (2005b). International Trade: US Trade Policy. Retrieved September 20, 2011, from http://www.americans-world.org/digest/global_issues/intertrade

World Public Opinion. (2006a). World Publics See European Union as a Positive influence. Retrieved September 12, 2011, from http://worldpublicopinion.org/incl/printable_version.php?pnt=335

World Public Opinion. (2006b). US Role in the World. Retrieved September 12, 2011, from $\mathrm{http} / / / \mathrm{www}$.americans-world.org/digest/overview/us_role/hegemonic-role.cfm

World Public Opinion. (2007). World Publics See European Union as a Positive Influence. Retrieved October 24, 2011, from http://www.worldpublicopion.org/pipa/articles/views

World Public Opinion. (2008). Mostly Positive Assessment of EU Influence. Retrieved September 27, 2011, from http://worldpublicopinion.org/pipa/articles/breuropera/458.php?lb=breu\&pnt+458\&nid

World Public Opinion. (2011). Views of the European Union's Influence. Retrieved October 24, 2011, from http://www.worldpublicopion.org/pipa/pdf/mar11/BBCEvalsUS 